Article

\title{
A Polyol-Polyol Super-Carbon-Chain Compound Containing Thirty-Six Carbon Stereocenters from the Dinoflagellate Amphidinium gibbosum: Absolute Configuration and Multi-Segment Modification
}

\author{
Wan-Shan $\mathrm{Li}^{1}{ }^{1}$, Zeng Luo ${ }^{1}$, Yan-Lan Zhu ${ }^{1}$, Yi Yu ${ }^{2}$, Jun $\mathrm{Wu}^{1,3, *}$ and Li Shen ${ }^{2, *}$ \\ 1 School of Pharmaceutical Sciences, Southern Medical University, 1838 Guangzhou Avenue North, \\ Guangzhou 510515, China; liwanshan@hainnu.edu.cn (W.-S.L.); luozeng1996@i.smu.edu.cn (Z.L.); \\ zyl1120@i.smu.edu.cn (Y.-L.Z.) \\ 2 Marine Drugs Research Center, College of Pharmacy, Jinan University, 601 Huangpu Avenue West, \\ Guangzhou 510632, China; yiyu1993@stu2018.jnu.edu.cn \\ 3 Institute of Marine Biomedicine, Shenzhen Polytechnic, Shenzhen 518055, China \\ * Correspondence: wwujun68@smu.edu.cn (J.W.); shenli6052@jnu.edu.cn (L.S.); Tel.: +86-20-61648711 (J.W.); \\ $+86-20-85222050$ (L.S.)
}

Received: 26 October 2020; Accepted: 22 November 2020; Published: 26 November 2020

\begin{abstract}
A super-carbon-chain compound, named gibbosol C, featuring a polyoxygenated $\mathrm{C}_{70}$-linearcarbon-chain backbone encompassing two acyclic polyol chains, was obtained from the South China Sea dinoflagellate Amphidinium gibbosum. Its planar structure was elucidated by extensive NMR investigations, whereas its absolute configurations, featuring the presence of 36 carbon stereocenters and 30 hydroxy groups, were successfully established by comparison of NMR data of the ozonolyzed products with those of gibbosol A, combined with J-based configuration analysis, Kishi's universal NMR database, and the modified Mosher's MTPA ester method. Multi-segment modification was revealed as the smart biosynthetic strategy for the dinoflagellate to create remarkable super-carbon-chain compounds with structural diversity.
\end{abstract}

Keywords: marine dinoflagellate; Amphidinium gibbosum; super-carbon-chain compound; absolute configuration; multi-segment modification

\section{Introduction}

Marine dinoflagellates produce huge organic molecules, particularly super-carbon-chain compounds (SCCCs), which are complex natural products with numerous carbon stereocenters on a long-carbon-chain backbone [1-4]. According to the structural feature of backbones, SCCCs can be categorized into two classes, viz., polyol-polyene and polyol-polyol compounds.

To date, most reported SCCCs are polyol-polyene compounds, such as amphidinol homologs [5-16] and karlotoxin congeners [17-22], characterized by the presence of both a polyol and a polyene chain, connected by a central core containing two tetrahydropyran rings. Polyol-polyene compounds, mainly isolated from marine dinoflagellates of the genera Amphidinium and Karlodinium, exhibit antifungal, antitumor, antiosteoclastic, and analgesic effects [5-22]. These SCCCs can specifically bind to membrane cholesterol or ergosterol and then disrupt cell membranes without altering their integrity [23].

Polyol-polyol compounds, however, are SCCCs featuring the presence of two polyol chains connected by a central core containing tetrahydropyran rings. So far, few examples have been reported. Ostreol B, isolated from the marine dinoflagellate Ostreopsis cf. ovata, could be classified as a polyol-polyol compound, although it only contains a tetrahydropyran ring as the central 
core [24]. Previously, two SCCCs with activation or inhibitory effects on the expression of vascular cell adhesion molecule 1, named gibbosols A and B (Figure 1a), were obtained by our team from the South China Sea dinoflagellate Amphidinium gibbosum. After years of unremitting effort, the planar structures and absolute configurations of these SCCC s have been completely established by a combined chemical, spectroscopic, and computational approach [25]. Gibbosols A and B represent a new type of polyol-polyol SCCC. During our ongoing investigation of SCCCs from the same dinoflagellate, a minor polyol-polyol SCCC, named gibbosol C (1) (3.0 mg) (Figure 1b), was obtained by the aid of the UPLC-MS/MS technique. The structures of the C-1-C-4, C-11-C-17, and C-34-C-35 segments within the starting polyol chain of gibbosol C (1) were different from those of gibbosol A. In this work, the isolation, planar structure elucidation, and stereochemical assignment of gibbosol C (1) are reported.
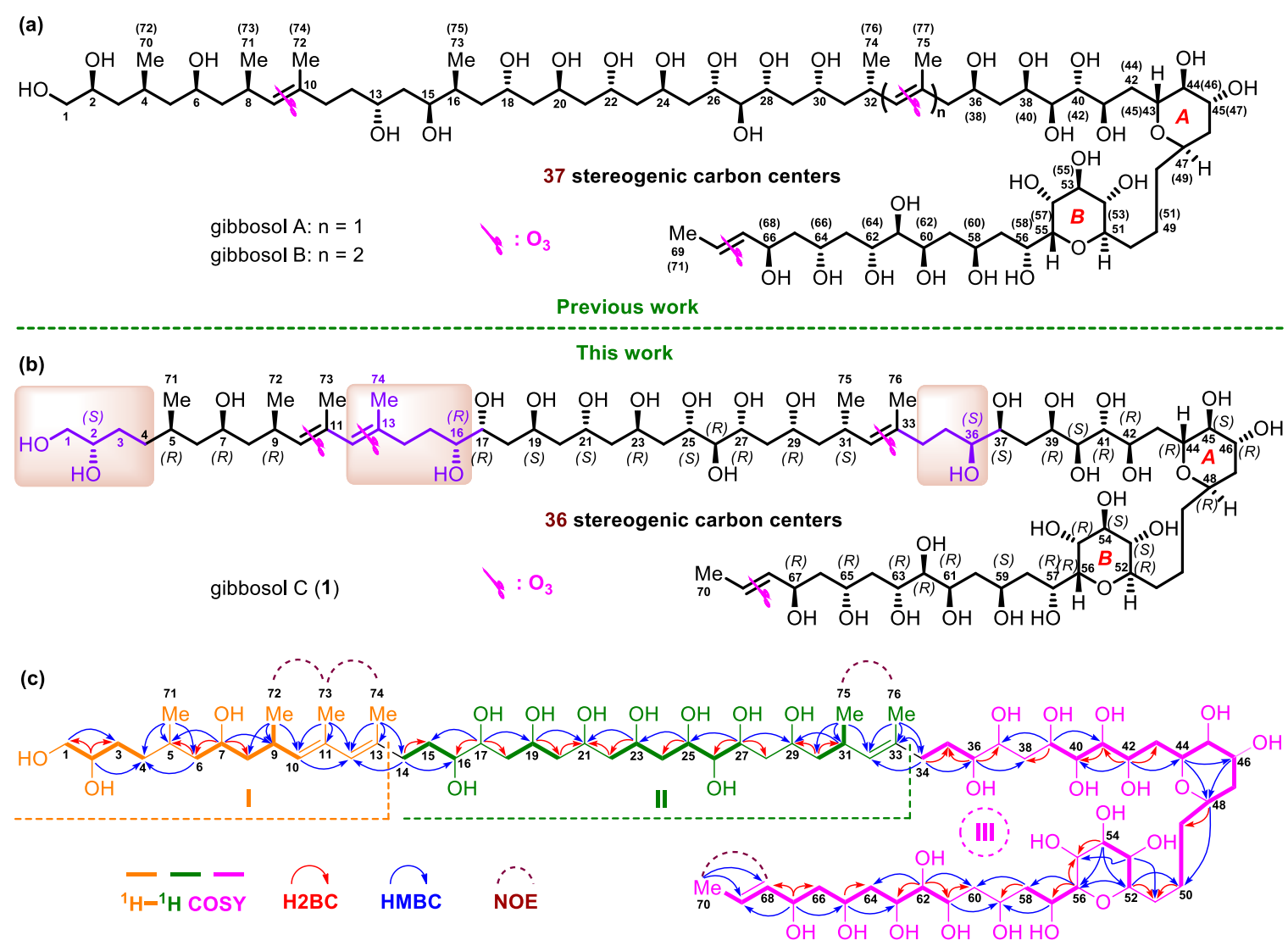

Figure 1. (a) The structures and absolute configurations of gibbosols A and B. (b) The structure and absolute configurations of gibbosol C (1). (c) Key ${ }^{1} \mathrm{H}-{ }^{1} \mathrm{H}$ COSY, H2BC, and HMBC correlations and diagnostic NOE interactions of gibbosol C (1).

\section{Results and Discussion}

\subsection{Planar Structure and Ozonolysis of Gibbosol C (1)}

The molecular formula of 1 was established as $\mathrm{C}_{76} \mathrm{H}_{142} \mathrm{O}_{32}$ with six degrees of unsaturation by the positive high resolution-electrospray ionization-mass spectrometry [(+)-HR-ESI-MS)] ions at $m / z$ $784.4814\left([\mathrm{M}+2 \mathrm{H}]^{2+}\right.$, calcd 784.4815) and $1567.9579\left([\mathrm{M}+\mathrm{H}]^{+}\right.$, calcd 1567.9557). According to the ${ }^{1} \mathrm{H}$ and ${ }^{13} \mathrm{C}$ NMR data of $\mathbf{1}$ (Table 1), four degrees of unsaturation result from four carbon-carbon double bonds. Thus, the molecule must contain two rings. The ${ }^{13} \mathrm{C}$ NMR data and the DEPT135 experiment of 1 indicated the presence of 76 carbon resonances that can be categorized as seven methyl groups, 25 methylene groups (including an oxymethylene), 41 methine groups (including 5 olefinic and 33 oxymethine groups), and three non-protonated olefinic carbons. 
Table 1. ${ }^{1} \mathrm{H}(700 \mathrm{MHz})$ and ${ }^{13} \mathrm{C}(175 \mathrm{MHz}) \mathrm{NMR}$ data for $\mathbf{1}$ in $\mathrm{CD}_{3} \mathrm{OD}$.

\begin{tabular}{|c|c|c|}
\hline No. & $\delta_{\mathrm{H}}(J$ in $\mathrm{Hz})$ & $\delta_{\mathrm{C}}$, Type \\
\hline $1 \mathrm{a}$ & $3.41, \mathrm{~m}$ & \multirow{2}{*}{$67.4, \mathrm{CH}_{2}$} \\
\hline $1 b$ & $3.45, \mathrm{~m}$ & \\
\hline 2 & $3.53, \mathrm{~m}$ & 73.6, $\mathrm{CH}$ \\
\hline $3 a$ & $1.39, \mathrm{~m}$ & \multirow{2}{*}{$31.9, \mathrm{CH}_{2}$} \\
\hline $3 b$ & $1.48, \mathrm{~m}$ & \\
\hline $4 a$ & $1.32, \mathrm{~m}$ & \multirow{2}{*}{$34.8, \mathrm{CH}_{2}$} \\
\hline $4 b$ & $1.32, \mathrm{~m}$ & \\
\hline 5 & $1.65, \mathrm{~m}^{\mathrm{f}}$ & $30.5, \mathrm{CH}$ \\
\hline $6 a$ & $1.12, \mathrm{~m}$ & \multirow{2}{*}{ 47.1, $\mathrm{CH}_{2}$} \\
\hline $6 b$ & $1.46, \mathrm{~m}$ & \\
\hline 7 & $3.62, \mathrm{~m}$ & $68.5, \mathrm{CH}$ \\
\hline $8 \mathrm{a}$ & $1.28, \mathrm{~m}$ & \multirow{2}{*}{ 47.4, $\mathrm{CH}_{2}$} \\
\hline $8 b$ & $1.43, \mathrm{~m}^{\mathrm{a}}$ & \\
\hline 9 & $2.74, \mathrm{~m}$ & $30.6, \mathrm{CH}$ \\
\hline 10 & 4.92, br d $(9.8)^{\mathrm{i}}$ & $136.2, \mathrm{CH}$ \\
\hline 11 & & 133.3, qC \\
\hline 12 & 5.67, br s & $130.3, \mathrm{CH}$ \\
\hline 13 & & $136.3, \mathrm{qC}$ \\
\hline $14 a$ & $2.08, \mathrm{~m}$ & \multirow{2}{*}{ 37.7, $\mathrm{CH}_{2}$} \\
\hline $14 b$ & $2.26, \mathrm{~m}$ & \\
\hline $15 a$ & $1.47, \mathrm{~m}$ & \multirow{2}{*}{ 32.3, $\mathrm{CH}_{2}$} \\
\hline $15 b$ & $1.74, \mathrm{~m}$ & \\
\hline 16 & $3.42, \mathrm{~m}$ & 75.81, CH \\
\hline 17 & $3.70, \mathrm{~m}$ & $72.8, \mathrm{CH}$ \\
\hline $18 \mathrm{a}$ & $1.50, \mathrm{~m}$ & \multirow{2}{*}{$41.2, \mathrm{CH}_{2}$} \\
\hline $18 \mathrm{~b}$ & $1.67, \mathrm{~m}^{\mathrm{e}}$ & \\
\hline 19 & $4.10, \mathrm{~m}$ & $66.5, \mathrm{CH}$ \\
\hline $20 a$ & $1.58, \mathrm{~m}^{\mathrm{b}}$ & \multirow{2}{*}{$46.9, \mathrm{CH}_{2}$} \\
\hline $20 \mathrm{~b}$ & $1.58, \mathrm{~m}^{\mathrm{b}}$ & \\
\hline 21 & $4.09, \mathrm{~m}^{\mathrm{j}}$ & $66.4, \mathrm{CH}$ \\
\hline $22 \mathrm{a}$ & $1.58, \mathrm{~m}^{\mathrm{b}}$ & \multirow{2}{*}{$46.9, \mathrm{CH}_{2}$} \\
\hline $22 b$ & $1.58, \mathrm{~m}^{\mathrm{b}}$ & \\
\hline 23 & $4.12, \mathrm{~m}$ & $66.3, \mathrm{CH}$ \\
\hline $24 a$ & $1.54, \mathrm{~m}$ & \multirow{2}{*}{$41.5, \mathrm{CH}_{2}$} \\
\hline $24 b$ & $1.79, \mathrm{~m}$ & \\
\hline 25 & $3.88, \mathrm{~m}$ & $70.5, \mathrm{CH}$ \\
\hline 26 & $3.37 \mathrm{t},(6.3)$ & $78.8, \mathrm{CH}$ \\
\hline 27 & $3.83, \mathrm{~m}$ & 73.1, CH \\
\hline $28 \mathrm{a}$ & $1.58, \mathrm{~m}^{\mathrm{b}}$ & \multirow{2}{*}{$41.0, \mathrm{CH}_{2}$} \\
\hline $28 \mathrm{~b}$ & $1.80, \mathrm{~m}$ & \\
\hline 29 & $3.78, \mathrm{~m}$ & $70.2, \mathrm{CH}$ \\
\hline $30 a$ & $1.35, \mathrm{~m}$ & \multirow{2}{*}{$46.8, \mathrm{CH}_{2}$} \\
\hline $30 \mathrm{~b}$ & $1.43, \mathrm{~m}^{\mathrm{a}}$ & \\
\hline
\end{tabular}


Table 1. Cont.

\begin{tabular}{|c|c|c|}
\hline No. & $\delta_{\mathrm{H}}(J$ in $\mathrm{Hz})$ & $\delta_{\mathrm{C}}$, Type \\
\hline 31 & $2.69, \mathrm{~m}$ & $30.1, \mathrm{CH}$ \\
\hline 32 & 4.92, br d $(9.8)^{\mathrm{i}}$ & $132.1, \mathrm{CH}$ \\
\hline 33 & & $135.5, \mathrm{CH}$ \\
\hline $34 a$ & $2.04, \mathrm{~m}$ & \multirow{2}{*}{$37.1, \mathrm{CH}_{2}$} \\
\hline $34 b$ & $2.19, \mathrm{~m}$ & \\
\hline $35 a$ & $1.55, \mathrm{~m}^{\mathrm{c}}$ & \multirow{2}{*}{$32.44, \mathrm{CH}_{2}$} \\
\hline $35 b$ & $1.69, \mathrm{~m}$ & \\
\hline 36 & $3.44, \mathrm{~m}$ & $74.7, \mathrm{CH}$ \\
\hline 37 & $3.69, \mathrm{~m}$ & $73.5, \mathrm{CH}$ \\
\hline $38 \mathrm{a}$ & $1.77, \mathrm{~m} \mathrm{~g}$ & \multirow{2}{*}{$37.4, \mathrm{CH}_{2}$} \\
\hline $38 \mathrm{~b}$ & $1.81, \mathrm{~m}$ & \\
\hline 39 & $4.13, \mathrm{~m}$ & $70.36, \mathrm{CH}$ \\
\hline 40 & $3.46, \mathrm{~m}$ & $74.6, \mathrm{CH}$ \\
\hline 41 & $3.69, \mathrm{~m}$ & 75.7, $\mathrm{CH}$ \\
\hline 42 & $4.04, \mathrm{~m}$ & $70.06, \mathrm{CH}$ \\
\hline $43 a$ & $1.77, \mathrm{~m}^{\mathrm{g}}$ & \multirow{2}{*}{$34.9, \mathrm{CH}_{2}$} \\
\hline $43 b$ & $1.98, \mathrm{~m}$ & \\
\hline 44 & $3.67, \mathrm{~m}$ & $70.9, \mathrm{CH}$ \\
\hline 45 & $3.03, \mathrm{t}(8.4)$ & $77.6, \mathrm{CH}$ \\
\hline 46 & $3.75, \mathrm{~m}$ & $70.4, \mathrm{CH}$ \\
\hline $47 a$ & $1.70, \mathrm{~m}$ & \multirow{2}{*}{$37.6, \mathrm{CH}_{2}$} \\
\hline $47 \mathrm{~b}$ & $1.88, \mathrm{~m}$ & \\
\hline 48 & $3.93, \mathrm{~m}$ & $73.2, \mathrm{CH}$ \\
\hline $49 a$ & $1.38, \mathrm{~m}$ & \multirow{2}{*}{$32.4, \mathrm{CH}_{2}$} \\
\hline $49 \mathrm{~b}$ & $1.91, \mathrm{~m}$ & \\
\hline $50 a$ & $1.53, \mathrm{~m}$ & \multirow{2}{*}{ 23.4, $\mathrm{CH}_{2}$} \\
\hline $50 \mathrm{~b}$ & $1.53, \mathrm{~m}$ & \\
\hline $51 \mathrm{a}$ & $1.52, \mathrm{~m}^{\mathrm{d}}$ & \multirow{2}{*}{$32.8, \mathrm{CH}_{2}$} \\
\hline $51 b$ & $1.75, \mathrm{~m}$ & \\
\hline 52 & $3.41, \mathrm{~m}$ & $76.5, \mathrm{CH}$ \\
\hline 53 & $3.14, \mathrm{t}(7.7)$ & $75.2, \mathrm{CH}$ \\
\hline 54 & $3.72, \mathrm{t}(7.7)$ & $75.1, \mathrm{CH}$ \\
\hline 55 & $3.78, \mathrm{~m}$ & $73.8, \mathrm{CH}$ \\
\hline 56 & $3.60, \mathrm{dd}(9.1,4.9)$ & $75.76, \mathrm{CH}$ \\
\hline 57 & $4.39, \mathrm{~m}$ & 67.7, $\mathrm{CH}$ \\
\hline $58 \mathrm{a}$ & $1.52, \mathrm{~m}^{\mathrm{d}}$ & \multirow{2}{*}{ 42.1, $\mathrm{CH}_{2}$} \\
\hline $58 b$ & $1.85, \mathrm{~m}^{\mathrm{h}}$ & \\
\hline 59 & $4.09, \mathrm{~m}^{\mathrm{j}}$ & $67.1, \mathrm{CH}$ \\
\hline $60 a$ & $1.67, \mathrm{~m}^{\mathrm{e}}$ & \multirow{2}{*}{ 42.7, $\mathrm{CH}_{2}$} \\
\hline $60 \mathrm{~b}$ & $1.85, \mathrm{~m}^{\mathrm{h}}$ & \\
\hline 61 & $4.09, \mathrm{~m}$ & $69.7, \mathrm{CH}$ \\
\hline 62 & $3.24, \mathrm{dd}(7.7,1.4)$ & $77.1, \mathrm{CH}$ \\
\hline 63 & $3.82, \mathrm{~m}$ & $71.9, \mathrm{CH}$ \\
\hline
\end{tabular}


Table 1. Cont.

\begin{tabular}{|c|c|c|}
\hline No. & $\delta_{\mathrm{H}}(J$ in $\mathrm{Hz})$ & $\delta_{C}$, Type \\
\hline $64 a$ & $1.59, \mathrm{~m}$ & \multirow{2}{*}{$42.2, \mathrm{CH}_{2}$} \\
\hline $64 b$ & $1.94, \mathrm{~m}$ & \\
\hline 65 & $4.08, \mathrm{~m}^{\mathrm{j}}$ & 68.7, CH \\
\hline $66 a$ & $1.55, \mathrm{~m}^{\mathrm{c}}$ & \multirow{2}{*}{ 45.7, $\mathrm{CH}_{2}$} \\
\hline $66 b$ & $1.65, \mathrm{~m}^{\mathrm{f}}$ & \\
\hline 67 & $4.26, \mathrm{~m}$ & $70.1, \mathrm{CH}$ \\
\hline 68 & $\begin{array}{c}5.51, \mathrm{ddq}(14.7 \\
6.3,1.4)\end{array}$ & $135.9, \mathrm{CH}$ \\
\hline 69 & $5.66, \mathrm{~m}$ & $126.4, \mathrm{CH}$ \\
\hline 70 & 1.68, br d (6.3) & $17.9, \mathrm{CH}_{3}$ \\
\hline 71 & $0.88, \mathrm{~d}(6.3)$ & $19.7, \mathrm{CH}_{3}$ \\
\hline 72 & $0.96, \mathrm{~d}(6.3)$ & 22.2, $\mathrm{CH}_{3}$ \\
\hline 73 & 1.72, br s & $17.6, \mathrm{CH}_{3}$ \\
\hline 74 & 1.76, br s & $18.1, \mathrm{CH}_{3}$ \\
\hline 75 & $0.94, \mathrm{~d}(7.0)$ & $22.4, \mathrm{CH}_{3}$ \\
\hline 76 & 1.68, br s & 16.7, $\mathrm{CH}_{3}$ \\
\hline
\end{tabular}

a-j Overlapped signals assigned by ${ }^{1} \mathrm{H}-{ }^{1} \mathrm{H}$ COSY, $\mathrm{HSQC}, \mathrm{H} 2 \mathrm{BC}$, and $\mathrm{HMBC}$ spectra without designating multiplicity.

Three substructures, viz., I (from C-1 to C-13, C-71, C-72, C-73, and C-74, in orange), II (from C-14 to $\mathrm{C}-33$, C-75, and C-76, in green), and III (from C-34 to C-70, in pink), were determined by analysis of key ${ }^{1} \mathrm{H}-{ }^{1} \mathrm{H}$ COSY, H2BC, and HMBC correlations of $\mathbf{1}$ (Figure 1c).

For substructure $\mathbf{I}$, the linear connection of $\mathrm{C}-1$ to $\mathrm{C}-4$ was indicated by the proton spin system $\mathrm{H}_{2}-1-\mathrm{H}-2-\mathrm{H}_{2}-3-\mathrm{H}_{2}-4$, which was deduced from the corresponding ${ }^{1} \mathrm{H}-{ }^{1} \mathrm{H}$ COSY correlations; $\mathrm{H} 2 \mathrm{BC}$ correlations from H-2/C-1 and H-2/C-3; and HMBC correlations from H-2/C-4 and $\mathrm{H}_{2}-1 / \mathrm{C}-3$. Similarly, the linear connection of $\mathrm{C}-6$ to $\mathrm{C}-10$ and the branched connection of $\mathrm{C}-9$ and $\mathrm{C}-72$ were revealed by the proton spin system $\mathrm{H}_{2}-6-\mathrm{H}-7-\mathrm{H}_{2}-8-\mathrm{H}-9\left(\mathrm{H}_{3}-72\right)-\mathrm{H}-10$, H2BC correlations from H-7/C-6 and H-7/C-8, and $\mathrm{HMBC}$ correlations from $\mathrm{H}-7 / \mathrm{C}-9, \mathrm{H}_{3}-72 / \mathrm{C}-8, \mathrm{H}_{3}-72 / \mathrm{C}-9$, and $\mathrm{H}_{3}-72 / \mathrm{C}-10$. The linear connection of $\mathrm{C}-4$ to $\mathrm{C}-6$ and the branched connection of $\mathrm{C}-5$ and $\mathrm{C}-71$ were corroborated by the $\mathrm{H} 2 \mathrm{BC}$ correlation from $\mathrm{H}-6 / \mathrm{C}-5$ and $\mathrm{HMBC}$ cross-peaks from $\mathrm{H}_{3}-71 / \mathrm{C}-4, \mathrm{H}_{3}-71 / \mathrm{C}-5, \mathrm{H}_{3}-71 / \mathrm{C}-6$, and $\mathrm{H}-7 / \mathrm{C}-5$, whereas the linear connection of $C-10$ to $C-13$ and the branched connections from $C-11 / C-73$ and $C-13 / C-74$ were confirmed by HMBC cross-peaks from $\mathrm{H}-10 / \mathrm{C}-12, \mathrm{H}_{3}-73 / \mathrm{C}-10, \mathrm{H}_{3}-73 / \mathrm{C}-11, \mathrm{H}_{3}-73 / \mathrm{C}-12, \mathrm{H}_{3}-74 / \mathrm{C}-12$, and $\mathrm{H}_{3}-74 / \mathrm{C}-13$. Taken together, the planar structure of $\mathbf{I}$ was elucidated (Figure 1c).

For substructure II, the linear connection of C-14 to C-16 was revealed by ${ }^{1} \mathrm{H}-{ }^{1} \mathrm{H}$ COSY correlations between $\mathrm{H}_{2}-14 / \mathrm{H}_{2}-15$ and $\mathrm{H}_{2}-15 / \mathrm{H}-16$, $\mathrm{H} 2 \mathrm{BC}$ correlations between $\mathrm{H}_{2}-14 / \mathrm{C}-15$, and $\mathrm{HMBC}$ cross-peaks between $\mathrm{H}_{2}-14 / \mathrm{C}-16$. Similarly, the linear connection of $\mathrm{C}-16$ to $\mathrm{C}-27$ was corroborated by two proton spin systems, $\mathrm{H}_{2}-18-\mathrm{H}-19-\mathrm{H}_{2}-20$ and $\mathrm{H}_{2}-22-\mathrm{H}-23-\mathrm{H}_{2}-24-\mathrm{H}-25-\mathrm{H}-26-\mathrm{H}-27 ; \mathrm{H} 2 \mathrm{BC}$ correlations between H-17/C-16, H-17/C-18, H-19/C-20, H 2 -20/C-21, $\mathrm{H}_{2}-22 / \mathrm{C}-21, \mathrm{H}-23 / \mathrm{C}-22, \mathrm{H}-25 / \mathrm{C}-24$, and H-27/C-26; and key HMBC cross-peaks between H-17/C-15, H-17/C-19, H-19/C-21, H-23/C-21, $\mathrm{H}-25 / \mathrm{C}-23$, and $\mathrm{H}-27 / \mathrm{C}-25$. In addition, the linear connection of C-27 to C-33 and the branched connections between C-31/C-75 and C-33/C-76 were established by ${ }^{1} \mathrm{H}-{ }^{1} \mathrm{H}$ COSY correlations between $\mathrm{H}_{2}-30 / \mathrm{H}-31$ and $\mathrm{H}_{3}-75 / \mathrm{H}-31, \mathrm{H} 2 \mathrm{BC}$ correlations between $\mathrm{H}-27 / \mathrm{C}-28, \mathrm{H}_{2}-30 / \mathrm{C}-29$, and $\mathrm{H}_{2}-30 / \mathrm{C}-31$, and HMBC cross-peaks between H-27/C-29, H-31/C-29, H 3 -75/C-30, $\mathrm{H}_{3}-75 / \mathrm{C}-31, \mathrm{H}_{3}-75 / \mathrm{C}-32, \mathrm{H}_{3}-76 / \mathrm{C}-32$, and $\mathrm{H}_{3}-76 / \mathrm{C}-33$. Taken together, the planar structure of II was assigned (Figure 1c).

For substructure III, the linear connection of C-34 to C-70 was undoubtedly elucidated by ${ }^{1} \mathrm{H}-{ }^{1} \mathrm{H}$ COSY, H2BC, and HMBC correlations (Figure 1c). The linear connection of C-34 to C-36 was revealed by ${ }^{1} \mathrm{H}-{ }^{1} \mathrm{H}$ COSY correlations from $\mathrm{H}_{2}-34 / \mathrm{H}_{2}-35$ and $\mathrm{H}_{2}-35 / \mathrm{H}-36, \mathrm{H} 2 \mathrm{BC}$ correlations 
from $\mathrm{H}_{2}-34 / \mathrm{C}-35$ and $\mathrm{H}-36 / \mathrm{C}-35$, and $\mathrm{HMBC}$ cross-peaks from $\mathrm{H}_{2}-34 / \mathrm{C}-36$. The linear connections of C-39 to C-50, C-52 to C-54, C-56 to C-58, and C- 61 to C-70 were confirmed by four proton spin systems, viz., H-39-H-40-H-41-H-42- $\mathrm{H}_{2}-43-\mathrm{H}-44-\mathrm{H}-45-\mathrm{H}-46-\mathrm{H}_{2}-47-\mathrm{H}-48-\mathrm{H}_{2}-49-\mathrm{H}_{2}-50$, H-52-H-53-H-54,

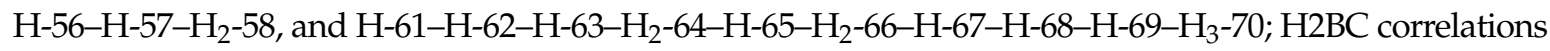
from H-41/C-40, H-42/C-41, H-42/C-43, H-48/C-49, H-56/C-57, H-62/C-61, H-62/C-63, H-65/C-64, H-67/C-66, and H-67/C-68; and HMBC cross-peaks from H-39/C-41, H-42/C-40, H-42/C-44, H-44/C-46, H-46/C-48, H-48/C-50, H-54/C-52, H-56/C-58, H-62/C-64, H-65/C-63, H-67/C-65, H-67/C-69, H 3 -70/C-68, and H3-70/C-69. The linear connections of $C-37$ to $C 39, C-50$ to $C 52, C-54$ to $C 56$, and $C-58$ to $C-61$ were resolved by H2BC correlations from H-39/C-38, H2-50/C-51, H-52/C-51, H-54/C-55, H-56/C-55, H 2 -58/C-59, and H-61/C-60 and crucial HMBC correlations from H-39/C-37, H-52/C-50, H-53/C-51, H-53/C-55, H-54/C-56, H-57/C-59, $\mathrm{H}_{2}-58 / \mathrm{C}-60, \mathrm{H}-61 / \mathrm{C}-59$, and H-62/C-60 (Figure 1c)

The presence of two tetrahydropyran moieties in III was indicated by isotope shift experiments, measured in both $\mathrm{CD}_{3} \mathrm{OD}$ and $\mathrm{CD}_{3} \mathrm{OH}$ [26]. Four oxymethine carbons involved in ether linkage, viz., C-44 ( $\delta 70.9), C-48(\delta 73.2), C-52(\delta 76.5)$, and C-56 ( 875.76$)$, did not exhibit a deuterium-induced isotope shift. The presence of ether bridges between C-44/C-48 and C-52/C-56, respectively, was further supported by HMBC cross-peaks from H-44/C-48 and H-52/C-56. Taken together, the backbone of III was assembled (Figure 1c).

Finally, crucial HMBC cross-peaks from $\mathrm{H}_{3}-74 / \mathrm{C}-14$ and $\mathrm{H}_{2}-14 / \mathrm{C}-12$ confirmed the connection between I and II through C-13-C-14, whereas the correlations from $\mathrm{H}_{3}-76 / \mathrm{C}-34, \mathrm{H}_{2}-34 / \mathrm{C}-32$, and $\mathrm{H}_{2}-34 / \mathrm{C}-33$ revealed the connection between II and III through C-33-C-34. The large value of ${ }^{3} J_{\mathrm{H}-68, \mathrm{H}-69}(14.7 \mathrm{~Hz})$ and NOE correlations from $\mathrm{H}_{3}-72 / \mathrm{H}_{3}-73, \mathrm{H}-10 / \mathrm{H}-12, \mathrm{H}_{3}-75 / \mathrm{H}_{3}-76, \mathrm{H}-32 / \mathrm{H}_{2}-34$, and $\mathrm{H}_{3}-70 / \mathrm{H}-68$ concluded that the geometries of the four carbon-carbon double bonds in $\mathbf{1}$, viz., $\mathrm{C} 10=\mathrm{C} 11, \mathrm{C} 12=\mathrm{C} 13, \mathrm{C} 32=\mathrm{C} 33$, and $\mathrm{C} 68=\mathrm{C} 69$, were all $E$-configured. Based on the above results, the planar structure of $\mathbf{1}$, containing 30 hydroxy groups and six pendant methyl moieties, was successfully established (Figure 1c).

Due to the heavy overlap of the ${ }^{1} \mathrm{H}$ and ${ }^{13} \mathrm{C}$ NMR signals of $\mathbf{1}$, the relative configurations of its stereogenic carbons could not be determined based on various 1D and 2D NMR data of the intact 1 . Comparison of the planar structure of $\mathbf{1}$ with that of gibbosol A (Figure 1) revealed that the structures of the C-5-C-11, C-17-C-33, and C-37-C-70 segments in 1 are the same as those of the C-4-C-10, C-18-C-34, and C-36-C-69 segments in gibbosol A, respectively. Based on the same biosynthetic machinery, the absolute configurations of the corresponding segments above should be identical. With detailed NMR data of three ozonolyzed products of gibbosol A (viz., gAa-c, Figure 2a) at hand [25], ozonolysis reaction was carried out for $\mathbf{1}$ to obtain the corresponding NMR data for comparison. As a result, $\mathrm{O}_{3} / \mathrm{NaBH}_{4}$-mediated cleavage of the carbon-carbon double bonds of $\mathbf{1}$ afforded three main fragments, viz., $\mathbf{1 a}, \mathbf{1} \mathbf{b}$, and $\mathbf{1 c}$ (Figure 2b, Tables S1-S3). Both $\mathbf{1 b}$ and $\mathbf{1 c}$ were obtained as epimeric pairs at C-13 and C-33, respectively.

\subsection{Relative and Absolute Configurations of Gibbosol C (1)}

Because gibbosols $\mathrm{A}$ and $\mathrm{C}$ were produced by the same marine dinoflagellate, the common biosynthetic origins of the two SCCCs should lead to identical absolute configurations of the corresponding segments in the three main pairs of the ozonolyzed fragments above. Detailed analysis of the NMR data led to the conclusion that the relative configurations of $\mathbf{1 a}, \mathbf{1} \mathbf{b}$, and $\mathbf{1 c}$ were similar to those of gAa, gAb, and gAc, respectively, except for the insertion of an additional methylene group between $\mathrm{C}-2$ and $\mathrm{C}-4$ in $\mathbf{1 a}$, the presence of an additional 16-OH group in $\mathbf{1 b}$ and an additional 36-OH group in 1c, and the absence of the 13,15-diol and 16-Me (Me-73 in gAb) groups in $\mathbf{1 b}$ (Figure 2). Coincidentally, all these modifications appear on the starting segments within three ozonolyzed products of gibbosol A [25].

For the C-5-C-7 segment of 1a, J-based configuration analysis (JBCA) $[27,28]$ was used (Figure 3a). ${ }^{3} J_{\mathrm{H}, \mathrm{H}}$ values were measured by $2 \mathrm{D} J$-resolved spectroscopy (2D JRES), whereas ${ }^{2,3} J_{\mathrm{C}, \mathrm{H}}$ values were obtained by the HETLOC experiment. The anti orientations between $\mathrm{H}-5 / \mathrm{H}-6 \mathrm{a}$ and $\mathrm{H}-7 / \mathrm{H}-6 \mathrm{~b}$ were 
assigned by the large values of ${ }^{3} J_{\mathrm{H}-5, \mathrm{H}-6 \mathrm{a}}(10.1 \mathrm{~Hz})$ and ${ }^{3} J_{\mathrm{H}-7, \mathrm{H}-6 \mathrm{~b}}(9.5 \mathrm{~Hz})$, respectively, whereas the gauche orientations between $\mathrm{H}-5 / \mathrm{H}-6 \mathrm{~b}$ and $\mathrm{H}-7 / \mathrm{H}-6 \mathrm{a}$ were proved by the small values of ${ }^{3} J_{\mathrm{H}-5, \mathrm{H}-6 \mathrm{~b}}$ $(3.9 \mathrm{~Hz})$ and ${ }^{3} J_{\mathrm{H}-7, \mathrm{H}-6 \mathrm{a}}(3.3 \mathrm{~Hz})$, respectively. The anti orientations between $\mathrm{C}-4 / \mathrm{H}-6 \mathrm{~b}$ and $7-\mathrm{OH} / \mathrm{H}-6 \mathrm{a}$ were deduced from the large value of ${ }^{3} J_{\mathrm{C}-4, \mathrm{H}-6 \mathrm{~b}}(6.8 \mathrm{~Hz})$ and the small value of ${ }^{2} J_{\mathrm{C}-7, \mathrm{H}-6 \mathrm{a}}(-1.9 \mathrm{~Hz})$, respectively. The gauche orientations between C-71/H-6a, C-71/H-6b, C-4/H-6a, C-8/H-6a, C-8/H-6b, and $7-\mathrm{OH} / \mathrm{H}-6 \mathrm{~b}$ were established by the small values of ${ }^{3} J_{\mathrm{C}-71, \mathrm{H}-6 \mathrm{a}}(3.0 \mathrm{~Hz}),{ }^{3} J_{\mathrm{C}-71, \mathrm{H}-6 \mathrm{~b}}(2.8 \mathrm{~Hz})$, ${ }^{3} J_{\mathrm{C}-4, \mathrm{H}-6 \mathrm{a}}(1.3 \mathrm{~Hz}),{ }^{3} J_{\mathrm{C}-8, \mathrm{H}-6 \mathrm{a}}(2.4 \mathrm{~Hz})$, and ${ }^{3} J_{\mathrm{C}-8, \mathrm{H}-6 \mathrm{~b}}(2.8 \mathrm{~Hz})$ and the large value of ${ }^{2} J_{\mathrm{C}-7, \mathrm{H}-6 \mathrm{~b}}(-6.6 \mathrm{~Hz})$, respectively. Thus, the relative configuration between Me-71/7-OH in 1a was concluded to be syn (Figure 3a).

(a)

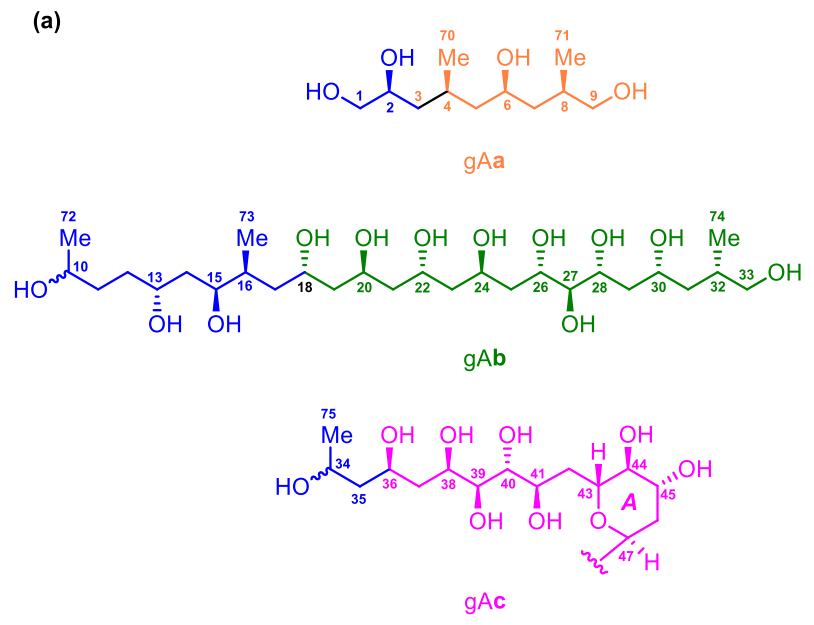

(b)<smiles>[M]C(O)CCC(O)CC(O)CO</smiles>

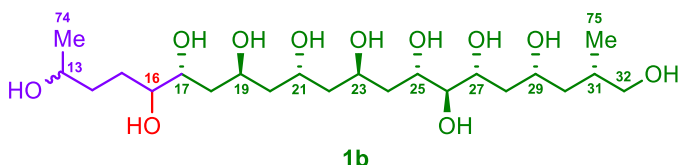

$1 \mathrm{~b}$

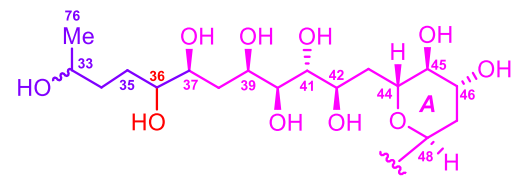

$1 \mathrm{c}$

Figure 2. (a) Structures of the ozonolyzed fragments gAa-c of gibbosol A. (b) Structures of the ozonolyzed fragments 1a-1c of gibbosol C (1).

The intermediate values of ${ }^{3} J_{\mathrm{H}-7, \mathrm{H}-8 \mathrm{a}}(7.6 \mathrm{~Hz})$ and ${ }^{3} J_{\mathrm{H}-7, \mathrm{H}-8 \mathrm{~b}}(5.2 \mathrm{~Hz})$ indicated two interconverting conformations for both H-7/H-8a and H-7/H-8b. Similarly, those of ${ }^{2} J_{\mathrm{C}-7, \mathrm{H}-8 \mathrm{~b}}(-3.1 \mathrm{~Hz})$ and ${ }^{3} J_{\mathrm{C}-6, \mathrm{H}-8 \mathrm{a}}$ $(3.6 \mathrm{~Hz})$ suggested two alternating conformations for both $7-\mathrm{OH} / \mathrm{H}-8 \mathrm{~b}$ and $\mathrm{C}-6 / \mathrm{H}-8 \mathrm{a}$. The large value of ${ }^{2} J_{\mathrm{C}-7, \mathrm{H}-8 \mathrm{a}}(-6.1 \mathrm{~Hz})$ and the small value of ${ }^{3} J_{\mathrm{C}-6, \mathrm{H}-8 \mathrm{~b}}(1.1 \mathrm{~Hz})$ revealed that both $7-\mathrm{OH} / \mathrm{H}-8 \mathrm{a}$ and $\mathrm{C}-6 / \mathrm{H}-8 \mathrm{~b}$ remained in gauche orientations. Thus, two alternating conformers were assigned for the C-7-C-8 segment (Figure S1). Similarly, the intermediate values of ${ }^{3} J_{\mathrm{H}-9, \mathrm{H}-8 \mathrm{a}}(6.2 \mathrm{~Hz})$ and ${ }^{3} \mathrm{~J}_{\mathrm{H}-9, \mathrm{H}-8 \mathrm{~b}}$ $(7.2 \mathrm{~Hz})$ indicated two interconverting conformations for both $\mathrm{H}-9 / \mathrm{H}-8 \mathrm{a}$ and $\mathrm{H}-9 / \mathrm{H}-8 \mathrm{~b}$. Those of ${ }^{3} J_{\mathrm{C}-72, \mathrm{H}-8 \mathrm{~b}}(4.2 \mathrm{~Hz})$ and ${ }^{3} J_{\mathrm{C}-10, \mathrm{H}-8 \mathrm{a}}(3.3 \mathrm{~Hz})$ suggested two alternating conformations for both $\mathrm{C}-72 / \mathrm{H}-8 \mathrm{~b}$ and C-10/H-8a. The small values of ${ }^{3} J_{\mathrm{C}-72, \mathrm{H}-8 \mathrm{a}}(1.8 \mathrm{~Hz})$ and ${ }^{3} J_{\mathrm{C}-10, \mathrm{H}-8 \mathrm{~b}}(2.3 \mathrm{~Hz})$ revealed that both $\mathrm{C}-72 / \mathrm{H}-8 \mathrm{a}$ and $\mathrm{C}-10 / \mathrm{H}-8 \mathrm{~b}$ were in gauche orientations. Therefore, two alternating conformers were assigned for the C-8-C-9 segment. Based on the results above, the relative configuration between 7-OH/Me-72 was determined as syn (Figure 3a).

To determine the absolute configurations of C-2, C-7, and C-9 in 1a, the modified Mosher's MTPA method was used. Through a comparison of the sign of $\Delta \delta^{S R}$ values between 1as/1ar, the absolute configurations of C-2 and C-7 in 1a were determined to be $S$ and $R$ (Figure 3b), respectively [29]. In addition, the absolute configuration of $C-9$ was assigned as $R$ by the widely separated $\mathrm{H}_{2}-10$ signals of 1 ar $(\delta 4.29,4.18)$ when compared with those of 1 as $(\delta 4.18,4.13)[30,31]$. Based on this syn relationship between Me-71 and 7-OH, the absolute configuration of C-5 in 1a was established as $R$. Therefore, the absolute configurations of the stereogenic carbons in 1a were established as $2 S, 5 R, 7 R, 9 R$ (Figure 3b), which are the same as those in gAa. 
(a) $\mathrm{C}-16 \sim \mathrm{C}-17$

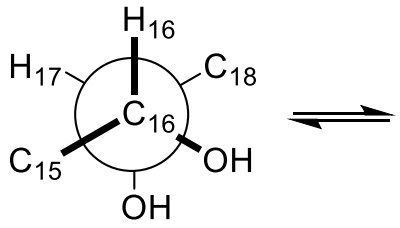

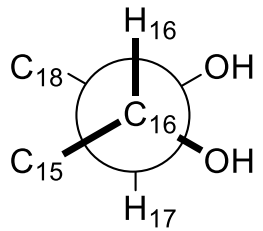

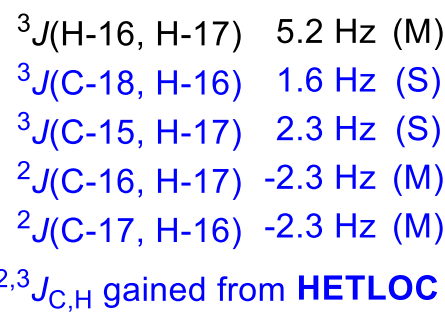

${ }^{2,3} J_{C, H}$ gained from HETLOC

${ }^{3} \mathrm{~J}(\mathrm{H}-16, \mathrm{H}-17) \quad 5.2 \mathrm{~Hz}(\mathrm{M})$

${ }^{3} \mathrm{~J}(\mathrm{C}-18, \mathrm{H}-16) \quad 1.7 \mathrm{~Hz}(\mathrm{~S})$

${ }^{3} \mathrm{~J}(\mathrm{C}-15, \mathrm{H}-17) \quad 2.5 \mathrm{~Hz}(\mathrm{~S})$

${ }^{2} \mathrm{~J}(\mathrm{C}-16, \mathrm{H}-17)-2.5 \mathrm{~Hz}(\mathrm{M})$

${ }^{2} \mathrm{~J}(\mathrm{C}-17, \mathrm{H}-16)-2.9 \mathrm{~Hz}(\mathrm{M})$

${ }^{2,3} J_{C, H}$ obtained from HECADE

(b) C-36 C-39<smiles>CC1CC2(O)C(O)[C@@H](C)C1C[C@H]2C</smiles>

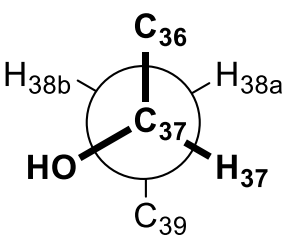

${ }^{3} J(\mathrm{H}-37, \mathrm{H}-38 \mathrm{a}) \quad 4.0 \mathrm{~Hz}(\mathrm{~S})$

${ }^{3} \mathrm{~J}(\mathrm{H}-37, \mathrm{H}-38 \mathrm{~b}) \quad 9.3 \mathrm{~Hz}(\mathrm{~L})$

${ }^{2} \mathrm{~J}(\mathrm{C}-37, \mathrm{H}-38 \mathrm{a})-1.9 \mathrm{~Hz}(\mathrm{~S})$

${ }^{2} J(\mathrm{C}-37, \mathrm{H}-38 \mathrm{~b})-5.5 \mathrm{~Hz}$ (L)

${ }^{3} \mathrm{~J}(\mathrm{C}-36, \mathrm{H}-38 \mathrm{a}) \quad 1.1 \mathrm{~Hz}(\mathrm{~S})$

${ }^{3} \mathrm{~J}(\mathrm{C}-36, \mathrm{H}-38 \mathrm{~b}) \quad 2.3 \mathrm{~Hz}(\mathrm{~S})$

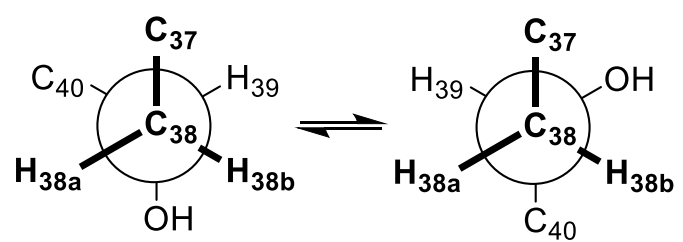

${ }^{3} J(\mathrm{H}-39, \mathrm{H}-38 \mathrm{a}) \quad 5.6 \mathrm{~Hz}(\mathrm{M})$

${ }^{3} \mathrm{~J}(\mathrm{H}-39, \mathrm{H}-38 \mathrm{~b}) \quad 7.2 \mathrm{~Hz}(\mathrm{M})$

${ }^{2} \mathrm{~J}(\mathrm{C}-39, \mathrm{H}-38 \mathrm{a})-3.7 \mathrm{~Hz}(\mathrm{M})$

${ }^{2} J(C-39, \mathrm{H}-38 \mathrm{~b}) \quad-5.3 \mathrm{~Hz}$ (L)

$3 \mathrm{~J}(\mathrm{C}-40, \mathrm{H}-38 \mathrm{a}) \quad 1.0 \mathrm{~Hz}(\mathrm{~S})$

${ }^{3} J(\mathrm{C}-40, \mathrm{H}-38 \mathrm{~b}) \quad 3.4 \mathrm{~Hz}(\mathrm{M})$

Figure 4. (a) Rotamers and coupling constants for the C-16-C-17 segment of $\mathbf{1 b}$. (b) Rotamers and coupling constants for the C36-C39 segment of 1c.

The relative configurations of the C-37-C-39 segment in 1c were determined to be the same as that of the C-36-C-38 segment of gAc by JBCA $[27,28]$ (Figure 4b). For the C-37-C-38 segment, the gauche orientation between H-37 and H-38a was determined by the small value of ${ }^{3} J_{\mathrm{H}-37, \mathrm{H}-38 \mathrm{a}}(4.0 \mathrm{~Hz})$, while the anti orientation between $\mathrm{H}-37$ and $\mathrm{H}-38 \mathrm{~b}$ was assigned by the large value of ${ }^{3} J_{\mathrm{H}-37, \mathrm{H}-38 \mathrm{~b}}$ $(9.3 \mathrm{~Hz})$. Similarly, the anti orientation between $37-\mathrm{OH}$ and $\mathrm{H}-38 \mathrm{a}$ was established by the small value of ${ }^{2} J_{\mathrm{C}-37, \mathrm{H}-38 \mathrm{a}}(-1.9 \mathrm{~Hz})$, whereas the gauche orientation between $37-\mathrm{OH}$ and $\mathrm{H}-38 \mathrm{~b}$ was established by the large value of ${ }^{2} J_{\mathrm{C}-37, \mathrm{H}-38 \mathrm{~b}}(-5.5 \mathrm{~Hz})$. In addition, the gauche orientations between $\mathrm{C}-36$ and $\mathrm{H}-38 \mathrm{a}$ and between $\mathrm{C}-36$ and $\mathrm{H}-38 \mathrm{~b}$ were suggested by the small values of ${ }^{3} J_{\mathrm{C}-36, \mathrm{H}-38 \mathrm{a}}(1.1 \mathrm{~Hz})$ and ${ }^{3} J_{\mathrm{C}-36, \mathrm{H}-38 \mathrm{~b}}(2.3 \mathrm{~Hz})$, respectively. For the C-38-C-39 segment, the intermediate values of ${ }^{3} J_{\mathrm{H}-39, \mathrm{H}-38 \mathrm{a}}$ $(5.6 \mathrm{~Hz})$ and ${ }^{3} J_{\mathrm{H}-39, \mathrm{H}-38 \mathrm{~b}}(7.2 \mathrm{~Hz})$ indicated two interconverting conformations for both $\mathrm{H}-39 / \mathrm{H}-38 \mathrm{a}$ and H-39/H-38b. Similarly, those of ${ }^{2} J_{\mathrm{C}-39, \mathrm{H}-38 \mathrm{a}}(-3.7 \mathrm{~Hz})$ and ${ }^{3} J_{\mathrm{C}-40, \mathrm{H}-38 \mathrm{~b}}(3.4 \mathrm{~Hz})$ suggested two 
alternating configurations for both $39-\mathrm{OH} / \mathrm{H}-38 \mathrm{a}$ and $\mathrm{C}-40 / \mathrm{H}-38 \mathrm{~b}$. The gauche orientations between $39-\mathrm{OH} / \mathrm{H}-38 \mathrm{~b}$ and $\mathrm{C}-40 / \mathrm{H}-38$ a were deduced from the large value of ${ }^{2} J_{\mathrm{C}-39, \mathrm{H}-38 \mathrm{~b}}(-5.3 \mathrm{~Hz})$ and the small value of ${ }^{3} J_{\mathrm{C}-40, \mathrm{H}-38 \mathrm{a}}(1.0 \mathrm{~Hz})$. Accordingly, the relationship between $37-\mathrm{OH}$ and $39-\mathrm{OH}$ was concluded to be syn. Finally, the relative configurations of the C-36-C-39 segment in 1c were concluded to be syn/syn (Figure 4b).

Furthermore, the relative configurations of the C-39-C-42 segment in 1c were assigned as syn/anti/anti (Table S1), the same as those of the C-38-C-41 segment in gAc [25], on the basis of Kishi's universal NMR database $[27,28]$.

Based on the absolute configurations of the C-17-C-25 and C-37-C-42 segments of 1, viz., $17 R, 19 S, 21 S, 23 R, 25 S$ and $37 S, 39 R, 40 S, 41 R, 42 R$, which were deduced from those of the corresponding segments of gibbosol A, the absolute configurations of C-16 in $\mathbf{1 b}$ and of C-37 in $\mathbf{1 c}$ were assigned as $R$ and $S$, respectively. In summary, the absolute configurations of 36 stereogenic carbons in gibbosol C (1) were established as $2 S, 5 R, 7 R, 9 R, 16 R, 17 R, 19 S, 21 S, 23 R, 25 S, 26 R, 27 R, 29 R, 31 S, 36 S, 37 S, 39 R, 40 S$, $41 R, 42 R, 44 R, 45 S, 46 R, 48 R, 52 R, 53 S, 54 S, 55 R, 56 R, 57 R, 59 S, 61 R, 62 R, 63 R, 65 R$, and 67R (Figure 1b).

In the pathogenesis of atherosclerosis, vascular cell adhesion molecule 1 (VCAM-1) and intercellular adhesion molecule 1 (ICAM-1) promote the accumulation of macrophages within the intima, leading to formation of the atherosclerotic lesion [34-36]. The above two adhesion molecules, particularly VCAM-1, have been considered as potential therapeutic targets for anti-atherogenic drug development [37]. It is important to find promising VCAM-1 inhibitors from natural products. Thus, the effects of gibbosol C (1) on VCAM-1 and ICAM-1 in human umbilical vein endothelial cells were investigated according to previous procedures [25]. At the concentration range of 10.0 and $100.0 \mu \mathrm{g} / \mathrm{mL}$, gibbosol C (1) showed no obvious activities on VCAM-1 and ICAM-1 expression (Figure S1), whereas gibbosol A displayed remarkable activation effects on VCAM-1 expression. On the contrary, gibbosol B exhibited marked inhibitory activities on VCAM-1 expression [25].

The co-isolation of gibbosols A-C enabled us to summarize their structural features, which may shed light on the biosynthesis of these polyol-polyol SCCCs. The 13 carbon central cores (C-43-C-55); the C-4-C-10, C-18-C-34, and C-36-C-42 segments of the starting polyol chain; and the whole terminal polyol chain (C-56-C-69) of gibbosol A are quite conserved, whereas other segments of the starting polyol chain are variable. Diverse modification patterns, such as insertion, substitution, oxidation, and reduction, appear on the C-1-C-4, C-11-C-17, or C-34-C-35 segment of the starting polyol chain of gibbosol A. In other words, multi-segment modification on the starting polyol chain is the biosynthetic strategy for the generation of gibbosol C (1).

In addition, glycolate should be the starter unit in the biosynthesis of gibbosols A-C [38]. Though acetate labeling patterns of some polyol-polyene SCCCs, such as amphidinols A [38], 4 [2,39], and $17[39,40]$, have been reported, no enzymatic mechanisms involved in the biosynthesis of these SCCCs have been uncovered so far [38-41]. Of course, the acetate labeling patterns of gibbosols A-C are worthy of further investigation in future.

\section{Materials and Methods}

\subsection{General Experimental Procedures}

HR-ESI-MS was obtained on a Bruker maXis ESI-QTOF mass spectrometer (Bruker Daltonics, Bremen, Germany) in the positive-ion mode. LR-ESI-MS was recorded on a Bruker amaZon SL mass spectrometer (Bruker Daltonics, Bremen, Germany) in both the positive- and negative-ion modes. One- and two-dimensional NMR spectra were measured on a Bruker AV-700 MHz NMR spectrometer (Bruker Scientific Technology Co. Ltd., Karlsruhe, Germany). UV spectra were recorded on a UV-2600 UV-Vis spectrophotometer (SHIMADZU, Kyoto, Japan) and optical rotations determined on an MCP 500 modular circular polarimeter (Anton Paar GmbH, Seelze, Germany) with a $1.0 \mathrm{~cm}$ cell at $25^{\circ} \mathrm{C}$. Preparative HPLC was performed on a Waters 2535 pump equipped with a $\mathrm{YMC} \mathrm{C}_{18}$ reversed-phase

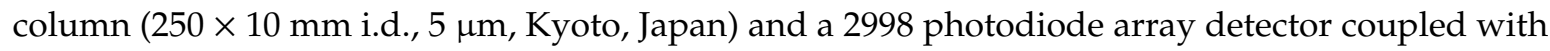


a 2424 evaporative light scattering detector (Waters Corporation, Milford, NY, USA). For column chromatography, silica gel (100-200 mesh, Qingdao Mar. Chem. Ind. Co. Ltd., Qingdao, China) and $\mathrm{C}_{18}$ reversed-phase silica gel (ODS-A-HG $12 \mathrm{~nm}, 50 \mu \mathrm{m}$, YMC, Kyoto, Japan) were employed.

\subsection{Isolation of the Dinoflagellate and the Large-Scale Culture}

The isolation and culture of the marine dinoflagellate Amphidinium gibbosum was described in our previous publication [25].

\subsection{Isolation of Gibbosol C (1)}

The filtrate of the culture medium $(1200 \mathrm{~L})$ was loaded onto a macroporous resin column (DIAION, HP-20, $120 \mathrm{~cm} \times 15 \mathrm{~cm}$ i.d.), eluted with freshwater to remove sea salt. The loaded sample was successively eluted with $25 \%, 50 \%, 75 \%$, and $95 \%$ aqueous ethanol. All the eluates were concentrated under reduced pressure to afford the resultant solid $\left(5.5 \mathrm{~g}\right.$ ), which was separated by a $\mathrm{C}_{18}$ reversed-phase column $(60 \times 5 \mathrm{~cm}$ i.d.), eluted with an aqueous methanol solution $(10 \%$ to $100 \%)$ to yield 83 fractions. UPLC-MS (Waters ACQUITY UPLC BEH $\mathrm{C}_{18} 150 \times 2.1 \mathrm{~mm}$ i.d., $1.7 \mu \mathrm{m}, \mathrm{MeCN} / \mathrm{H}_{2} \mathrm{O}$, from 5:95 to 98:2) was used for the detection of super-carbon-chain compounds in these fractions. Fractions 62 and 63 (23.6 mg) were combined and purified by HPLC (YMC-Pack $250 \times 4.6 \mathrm{~mm}$ i. d., $\mathrm{MeCN} / \mathrm{H}_{2} \mathrm{O}, 21: 79$ ) to give $1\left(3.2 \mathrm{mg}, t_{\mathrm{R}}=60.5 \mathrm{~min}\right)$.

Gibbosol C (1): Colorless solid, $[a]_{\mathrm{D}}^{25}=+9.3\left(c=0.08\right.$, methanol); UV $(\mathrm{MeCN}) \lambda_{\max }(\log \varepsilon) 203.6$ (3.9), 230.2 (3.6) nm; for ${ }^{1} \mathrm{H}$ and ${ }^{13} \mathrm{C}$ NMR spectroscopic data, see Table 1; HR-ESI-MS $m / z[\mathrm{M}+2 \mathrm{H}]^{2+}$ (calcd for $\mathrm{C}_{76} \mathrm{H}_{144} \mathrm{O}_{32}, 784.4814$, found 784.4815) and $[\mathrm{M}+\mathrm{H}]^{+}$(calcd for $\mathrm{C}_{76} \mathrm{H}_{143} \mathrm{O}_{32}, 1567.9579$, found 1567.9557).

\subsection{Ozonolysis}

Gibbosol C (1) (3.0 mg, $0.002 \mathrm{mM})$ was dissolved in a mixture of $\mathrm{CH}_{2} \mathrm{Cl}_{2}-\mathrm{MeOH}(1: 1$, each $2 \mathrm{~mL})$. Ozone was bubbled into the above solution at $-78^{\circ} \mathrm{C}$ for $2 \mathrm{~min}$. An excess amount of $\mathrm{NaBH}_{4}$ was then added and stirred at $-78^{\circ} \mathrm{C}$ for $3 \mathrm{~h}$. The reaction mixture was purified by a $\mathrm{C}_{18}$ reversed-phase silica gel column (Daisogel, SP-120-50-ODS-B, 3 g, $5.0 \mathrm{~cm} \times 1.0 \mathrm{~cm}$ i.d.), eluted with $10 \mathrm{~mL}$ of water followed by $15 \mathrm{~mL}$ of $\mathrm{MeOH}$, to afford three fractions. The second fraction was purified by HPLC (Cosmosil, HILIC, $250 \times 4.6 \mathrm{~mm}$ i. d., $\left.\mathrm{MeCN} / \mathrm{H}_{2} \mathrm{O}, 90: 10-50: 50\right)$ to afford three products, viz., fragments $1 \mathrm{a}\left(0.4 \mathrm{mg}, t_{\mathrm{R}}=\right.$ $4.9 \mathrm{~min}), \mathbf{1 b}\left(0.9 \mathrm{mg}, t_{\mathrm{R}}=50.8 \mathrm{~min}\right)$, and $1 \mathbf{c}\left(1.3 \mathrm{mg}, t_{\mathrm{R}}=72.7 \mathrm{~min}\right)$ (Figure 2$)$.

1a: For ${ }^{1} \mathrm{H}$ and ${ }^{13} \mathrm{C}$ NMR spectroscopic data, see Table S2; LR-ESI-MS $m / z 257.6[\mathrm{M}+\mathrm{Na}]^{+}$and $491.6[2 \mathrm{M}+\mathrm{Na}]^{+}$.

1b: For ${ }^{1} \mathrm{H}$ and ${ }^{13} \mathrm{C}$ NMR spectroscopic data, see Table S3; LR-ESI-MS $m / z 487.6[\mathrm{M}+\mathrm{H}]^{+}$and $509.5[\mathrm{M}+\mathrm{Na}]^{+}$.

1c: For ${ }^{1} \mathrm{H}$ and ${ }^{13} \mathrm{C}$ NMR spectroscopic data, see Table S4; LR-ESI-MS $m / z 869.4[\mathrm{M}+\mathrm{H}]^{+}$and $891.3[\mathrm{M}+\mathrm{Na}]^{+}$.

\subsection{Mosher's MTPA Esters 1as and 1ar}

The fragment 1a $(0.3 \mathrm{mg})$ was treated with $(R)-\mathrm{MTPACl}(8.0 \mu \mathrm{L})$ in dried pyridine $(0.8 \mathrm{~mL})$ at room temperature for $10 \mathrm{~h}$. The reaction mixture was concentrated and purified by HPLC (YMC-Pack $250 \mathrm{~cm} \times 4.6 \mathrm{~mm}$ i.d., $\left.\mathrm{MeCN} / \mathrm{H}_{2} \mathrm{O}, 92: 8\right)$ to afford the (S)-MTPA ester 1as (1.1 mg). The (R)-MTPA ester $\operatorname{1ar}(1.0 \mathrm{mg})$ was prepared in the same way. With the aid of key ${ }^{1} \mathrm{H}-{ }^{1} \mathrm{H}$ COSY correlations, ${ }^{1} \mathrm{H}$ NMR spectroscopic data of 1 as and 1ar were assigned (Table S5).

1as: For ${ }^{1} \mathrm{H}$ NMR spectroscopic data, see Table S5; LR-ESI-MS $m / z 1116.4\left[\mathrm{M}+\mathrm{NH}_{4}\right]^{+}$and 1121.2 $[\mathrm{M}+\mathrm{Na}]^{+}$.

1ar: For ${ }^{1} \mathrm{H}$ NMR spectroscopic data, see Table S5; LR-ESI-MS $m / z 1116.4\left[\mathrm{M}+\mathrm{NH}_{4}\right]^{+}$and 1121.3 $[\mathrm{M}+\mathrm{Na}]^{+}$. 


\section{Conclusions}

In summary, a new polyol-polyol SCCC, named gibbosol C, was isolated from the South China Sea dinoflagellate $A$. gibbosum. Its planar structure and absolute configurations, featuring the presence of 36 carbon stereocenters and 30 hydroxy groups, were successfully established by extensive NMR investigations, ozonolysis of the carbon-carbon double bonds, J-based configuration analysis, Kishi's universal NMR database, the modified Mosher's MTPA ester method, and comparison of the NMR data of the ozonolyzed products with those of gibbosol A. Multi-segment modification seems to be the smart biosynthetic strategy for the dinoflagellate to create remarkable SCCCs with diverse structures. Marine dinoflagellates of the genus Amphidinium harbor novel and complex SCCC biosynthetic routes. New integrated chemical, spectroscopic, and computational approaches or intelligent databases should be developed to cope with the stereochemical complexity of SCCCs. Evidently, specific carbon-carbon bond cleavages are an important means for the determination of the relative and absolute configurations of polyol-polyol SCCCs in the future.

Supplementary Materials: The following are available online at http://www.mdpi.com/1660-3397/18/12/590/s1, Tables S1-S5, Figure S1, ${ }^{1} \mathrm{H}-\mathrm{NMR}$ data for 1a-1c, 1as, and 1ar; and ${ }^{13} \mathrm{C}-\mathrm{NMR}$ data for 1a-1c (PDF). Copies of the high-performance liquid chromatogram, the UV spectrum, HR-ESI-MS for 1; LR-ESI-MS for 1a-1c, 1as, and 1ar; and $1 \mathrm{D}$ and $2 \mathrm{D}$ NMR spectra for 1, 1a-1c, 1as, and 1ar (PDF).

Author Contributions: L.S. and J.W. conceived and designed the experiments; Z.L. performed the large-scale culture of the marine dinoflagellate, W.-S.L. performed the chemistry part of the experiments and analyzed the data; Y.-L.Z. and Y.Y. performed the bioactivity part of the experiments and analyzed the data; W.-S.L. and J.W. wrote the draft; L.S. and J.W. revised the paper. All authors have read and agreed to the published version of the manuscript.

Funding: This work was financially supported by grants from the Guangdong Natural Science Funds for Distinguished Young Scholars, China (2020B1515020056) and the National Natural Science Foundation of China (31770377 and 81661148049).

Acknowledgments: The authors are grateful to Ai-Jun Sun and Yun Zhang (South China Sea Institute of Oceanology, Chinese Academy of Sciences) for the measurement of HR-ESI-MS. We thank Zhihui Xiao (Equipment Public Service Center, South China Sea Institute of Oceanology, Chinese Academy of Sciences) for recording the $700 \mathrm{MHz}$ NMR spectra.

Conflicts of Interest: The authors declare no conflict of interest.

\section{References}

1. Kobayashi, J.; Ishibashi, M. Bioactive metabolites of symbiotic marine microorganisms. Chem. Rev. 1993, 93, 1753-1769. [CrossRef]

2. Kobayashi, J.; Kubota, T. Bioactive macrolides and polyketides from marine dinoflagellates of the genus Amphidinium. J. Nat. Prod. 2007, 70, 451-460. [CrossRef] [PubMed]

3. Uemura, D. Bioorganic studies on marine natural products-diverse chemical structures and bioactivities. Chem. Rec. 2006, 6, 235-248. [CrossRef] [PubMed]

4. Kita, M.; Uemura, D. Marine huge molecules: The longest carbon chains in natural products. Chem. Rec. 2010, 10, 48-52. [CrossRef] [PubMed]

5. Satake, M.; Murata, M.; Yasumoto, T.; Fujita, T.; Naoki, H. Amphidinol, a polyhydroxypolyene antifungal agent with an unprecedented structure, from a marine dinoflagellate, Ampbidnium klebsii. J. Am. Chem. Soc. 1991, 113, 9859-9861. [CrossRef]

6. Murata, M.; Matsuoka, S.; Matsumori, N.; Paul, G.K.; Tachibana, K. Absolute configuration of amphidinol 3, the first complete structure determination from amphidinol homologues: Application of a new configuration analysis based on carbon-hydrogen spin-coupling constants. J. Am. Chem. Soc. 1999, 121, 870-871. [CrossRef]

7. Huang, X.; Zhao, D.; Guo, Y.; Wu, H.; Lin, L.; Wang, Z.; Ding, J.; Lin, Y. Lingshuiol, a novel polyhydroxyl compound with strongly cytotoxic activity from the marine dinoflagellate Amphidinium sp. Bioorg. Med. Chem. Lett. 2004, 14, 3117-3120.

8. Huang, X.; Zhao, D.; Guo, Y.; Wu, H.; Trivellone, E.; Cimino, G. Lingshuiols A and B, two new polyhydroxy compounds from the Chinese marine dinoflagellate Amphidinium sp. Tetrahedron Lett. 2004, 45, 5501-5504. [CrossRef] 
9. Washida, K.; Koyama, T.; Yamada, K.; Kita, M.; Uemura, D. Karatungiols A and B, two novel antimicrobial polyol compounds, from the symbiotic marine dinoflagellate Amphidinium sp. Tetrahedron Lett. 2006, 47, 2521-2525. [CrossRef]

10. Morsy, N.; Houdai, T.; Matsuoka, S.; Matsumori, N.; Adachi, S.; Oishi, T.; Murata, M.; Iwashita, T.; Fujita, T. Structures of new amphidinols with truncated polyhydroxyl chain and their membrane-permeabilizing activities. Bioorg. Med. Chem. 2006, 14, 6548-6554. [CrossRef]

11. Huang, S.; Kuo, C.; Lin, Y.; Chen, Y.; Lu, C. Carteraol E, a potent polyhydroxyl ichthyotoxin from the dinoflagellate Amphidinium carterae. Tetrahedron Lett. 2009, 50, 2512-2515. [CrossRef]

12. Hanif, N.; Ohno, O.; Kitamura, M.; Yamada, K.; Uemura, D. Symbiopolyol, a VCAM-1 inhibitor from a symbiotic dinoflagellate of the jellyfish Mastigias papua. J. Nat. Prod. 2010, 73, 1318-1322. [CrossRef] [PubMed]

13. Inuzuka, T.; Yamamoto, Y.; Yamada, K.; Uemura, D. Amdigenol A, a long carbon-backbone polyol compound, produced by the marine dinoflagellate Amphidinium sp. Tetrahedron Lett. 2012, 53, 239-242. [CrossRef]

14. Inuzuka, T.; Yamada, K.; Uemura, D. Amdigenols E and G, long carbon-chain polyol compounds, isolated from the marine dinoflagellate Amphidinium sp. Tetrahedron Lett. 2014, 55, 6319-6323. [CrossRef]

15. Satake, M.; Cornelio, K.; Hanashima, S.; Malabed, R.; Murata, M.; Matsumori, N.; Zhang, H.; Hayashi, F.; Mori, S.; Kim, J.S.; et al. Structures of the largest amphidinol homologues from the dinoflagellate Amphidinium carterae and structure-activity relationships. J. Nat. Prod. 2017, 80, 2883-2888. [CrossRef] [PubMed]

16. Martínez, K.A.; Lauritano, C.; Druka, D.; Romano, G.; Grohmann, T.; Jaspars, M.; Martín, J.; Díaz, C.; Cautain, B.; de la Cruz, M.; et al. Amphidinol 22, a new cytotoxic and antifungal amphidinol from the dinoflagellate Amphidinium carterae. Mar. Drugs 2019, 17, 385. [CrossRef]

17. Van Wagoner, R.M.; Deeds, J.R.; Satake, M.; Ribeiro, A.A.; Place, A.R.; Wright, J.L.C. Isolation and characterization of karlotoxin 1, a new amphipathic toxin from Karlodinium veneficum. Tetrahedron Lett. 2008, 49, 6457-6461. [CrossRef]

18. Peng, J.; Place, A.R.; Yoshida, W.; Anklin, C.; Hamann, M.T. Structure and absolute configuration of karlotoxin-2, an ichthyotoxin from the marine dinoflagellate Karlodinium veneficum. J. Am. Chem. Soc. 2010, 132, 3277-3279. [CrossRef]

19. Van Wagoner, R.M.; Deeds, J.R.; Tatters, A.O.; Place, A.R.; Tomas, C.R.; Wright, J.L.C. Structure and relative potency of several karlotoxins from Karlodinium veneficum. J. Nat. Prod. 2010, 73, 1360-1365. [CrossRef]

20. Waters, A.L.; Oh, J.; Place, A.R.; Hamann, M.T. Stereochemical studies of the karlotoxin class using NMR spectroscopy and DP4 chemical-shift analysis: Insights into their mechanism of action. Angew. Chem. Int. Ed. 2015, 54, 1-7. [CrossRef]

21. Cai, P.; He, S.; Zhou, C.; Place, A.R.; Had, S.; Ding, L.; Chen, H.; Jiang, Y.; Guo, C.; Xu, Y.; et al. Two new karlotoxins found in Karlodinium veneficum (strain GM2) from the East China Sea. Harm. Algae 2016, 58, 66-73. [CrossRef] [PubMed]

22. Rasmussen, S.A.; Binzer, S.B.; Hoeck, C.; Meier, S.; de Medeiros, L.S.; Andersen, N.G.; Place, A.; Nielsen, K.F.; Hansen, P.J.; Larsen, T.O. Karmitoxin: An amine-containing polyhydroxy-polyene toxin from the marine dinoflagellate Karlodinium armiger. J. Nat. Prod. 2017, 80, 1287-1293. [CrossRef] [PubMed]

23. Espiritu, R.A.; Matsumori, N.; Tsuda, M.; Murata, M. Direct and stereospecific interaction of amphidinol 3 with sterol in lipid bilayers. Biochemistry 2014, 53, 3287-3293. [CrossRef] [PubMed]

24. Hwang, B.S.; Yoon, E.Y.; Jeong, E.J.; Park, J.; Kim, E.-H.; Rho, J.-R. Determination of the absolute configuration of polyhydroxy compound ostreol B isolated from the dinoflagellate Ostreopsis cf. ovate. J. Org. Chem. 2018, 83, 194-202. [CrossRef]

25. Li, W.S.; Yan, R.J.; Yu, Y.; Shi, Z.; Mándi, A.; Shen, L.; Kurtán, T.; Wu, J. Determination of the absolute configuration of super-carbon-chain compounds by a combined chemical, spectroscopic, and computational approach: Gibbosols A and B. Angew. Chem. Int. Ed. 2020, 59, 13028-13036. [CrossRef]

26. Hamamoto, Y.; Tachibana, K.; Holland, P.T.; Shi, F.; Beuzenberg, V.; Itoh, Y.; Satake, M. Brevisulcenal-F: A polycyclic ether toxin associated with massive fish-kills in New Zealand. J. Am. Chem. Soc. 2012, 134, 4963-4968. [CrossRef]

27. Matsumori, N.; Kaneno, D.; Murata, M.; Nakamura, H.; Tachibana, K. Stereochemical determination of acyclic structures based on carbon-proton spin-coupling constants. A method of configuration analysis for natural products. J. Org. Chem. 1999, 64, 866-876. [CrossRef] 
28. Bifulco, G.; Dambruoso, P.; Gomez-Paloma, L.; Riccio, R. Determination of relative configuration in organic compounds by NMR spectroscopy and computational methods. Chem. Rev. 2007, 107, 3744-3779. [CrossRef]

29. Ohtani, I.; Kusumi, T.; Kashman, Y.; Kakisawa, H. High-field FT NMR application of Mosher's method. The absolute configurations of marine terpenoids. J. Am. Chem. Soc. 1991, 113, 4092-4096. [CrossRef]

30. De Riccardis, F.; Minale, L.; Riccio, R.; Giovannitti, B.; Iorrizi, M.; Debitus, C. Phosphated and sulphated marine polyhydroxylated steroids from the starfish Tremaster novaecaledonìe. Gazz. Chim. Ital. 1993, 123, 79-86.

31. Finamore, E.; Minale, L.; Riccio, R.; Rinaldo, G.; Zollo, F. Novel marine polyhydroxylated steroids from the starfish Myxoderma platyacanthum. J. Org. Chem. 1991, 56, 1146-1153. [CrossRef]

32. Higashibayashi, S.; Czechtizky, W.; Kobayashi, Y.; Kishi, Y. Universal NMR databases for contiguous polyols. J. Am. Chem. Soc. 2003, 125, 14379-14393. [CrossRef] [PubMed]

33. Seike, H.; Ghosh, I.; Kishi, Y. Attempts to assemble a universal NMR database without synthesis of NMR database compounds. Org. Lett. 2006, 8, 3861-3864. [CrossRef] [PubMed]

34. Preiss, D.J.; Sattar, N. Vascular cell adhesion molecule-1: A viable therapeutic target for atherosclerosis? Int. J. Clin. Pract. 2007, 61, 697-701. [CrossRef]

35. Jiao, H.L.; Zhang, Q.; Lin, Y.B.; Gao, Y.; Zhang, P. The ovotransferrin-derived peptide IRW attenuates lipopolysaccharide-induced inflammatory responses. BioMed Res. Int. 2019, 8676410. [CrossRef]

36. Park, J.-G.; Ryu, S.Y.; Jung, I.-H.; Lee, Y.-H.; Kang, K.J.; Lee, M.-R.; Lee, M.-N.; Sonn, S.K.; Lee, J.H.; Lee, H.; et al. Evaluation of VCAM-1 antibodies as therapeutic agent for atherosclerosis in apolipoprotein E-deficient mice. Atherosclerosis 2013, 226, 356-363. [CrossRef]

37. Ling, S.; Nheu, L.; Komesaroff, P.A. Cell adhesion molecules as pharmaceutical target in atherosclerosis. Mini-Rev. Med. Chem. 2012, 12, 175-183. [CrossRef]

38. Cutignano, A.; Nuzzo, G.; Sardo, A.; Fontana, A. The missing piece in biosynthesis of amphidinols: First evidence of glycolate as a starter unit in new polyketides from Amphidinium carterae. Mar Drugs 2017, $15,157$. [CrossRef]

39. Van Wagoner, R.M.; Satake, M.; Wright, J.L.C. Polyketide biosynthesis in dinoflagellates: What makes it different? Nat. Prod. Rep. 2014, 31, 1101-1137. [CrossRef]

40. Meng, Y.; Van Wagoner, R.M.; Misner, I.; Tomas, C.; Wright, J.L.C. Structure and biosynthesis of amphidinol 17, a hemolytic compound from Amphidinium carterae. J. Nat. Prod. 2010, 73, 409-415. [CrossRef]

41. Kellman, R.; Stüken, A.; Orr, R.J.S.; Svendsen, H.M.; Jakobsen, K.S. Biosynthesis and molecular genetics of polyketides in marine dinoflagellates. Mar. Drugs 2010, 8, 1011-1048. [CrossRef] [PubMed]

Publisher's Note: MDPI stays neutral with regard to jurisdictional claims in published maps and institutional affiliations.

(C) 2020 by the authors. Licensee MDPI, Basel, Switzerland. This article is an open access article distributed under the terms and conditions of the Creative Commons Attribution (CC BY) license (http://creativecommons.org/licenses/by/4.0/). 